\title{
ASSESSING THE PROTECTION OF WOMEN'S RIGHTS IN THE PERSPECTIVE OF FEMINISM DURING THE COVID-19 PANDEMIC
}

\author{
Siciliya Mardian Yoel $^{1}$ \\ ${ }^{1}$ Universitas Islam Kediri \\ Jl. Sersan Suharmaji No. 38, Kota Kediri, 64128 \\ Email: siciliya@uniska-kediri.ac.id
}

\begin{abstract}
This study aims to identify the laws and regulations that regulate women's human rights and analyze them using them to determine the effectiveness of these laws and regulations in protecting women's human rights during the pandemic. The research was conducted using normative legal research methods using a conceptual approach and a statutory approach. The collection of legal materials is carried out using a literature study and the legal materials will be analyzed using Feminist Legal Theory. The results of the study show that there are several women's human rights that have been regulated in Indonesian laws and regulations, including: (1) The right to be free from gender discrimination (UU HAM); (2) The right to justice and gender equality (UU HAM, UU PKDRT); (3) The right to get protection as a victim (UU PKDRT); (4) The right to recognition and respect for human rights in all matters relating to citizens (UU Kewarganegaraan); (5) The right to be free from racial discrimination (UU PTPPO); (6) Political Rights (UU Parpol, UU Pemilu); and (7) The right to be free from discriminatory treatment against a social group that is still underdeveloped (UU Parpol, UU Pemilu). With regard to these laws and regulations, by focusing only on aspects of legal protection, namely protection against violence (both physical and sexual) against women, it shows that the existing legal umbrella is not effective enough to protect women. This is because the existence of laws and regulations alone cannot guarantee the implementation of women's human rights. Legislation must be followed by gendersensitive law enforcement and no less important is a cultural change in society.
\end{abstract}

Keywords: Legal Protection, Women's Rights, Law Enforcement.

\section{A. INTRODUCTION}

Almost no one would have thought that in 2020, humans are forced to slow down and have to limit themselves to socializing with other humans if they don't want to contract a disease that can threaten their lives. Corona Virus Disease 2019 (COVID-19) is the cause of this slowdown in human activity, the disease

\footnotetext{
1 Tempo.co. (2020). WHO Tetapkan COVID 19
} sebagai Pandemi, Apa Maksudnya? 12 Maret which was first reported in Wuhan, China on December 31, 2019, became a global health issue and was later declared by the World Health Organization (WHO) a pandemic. This pandemic status was announced after being raised from epidemic status because COVID-19 has infected 125,000 people and killed 4.5000 more worldwide. ${ }^{1}$ The disease has

2020. https://dunia.tempo.co/read/1318511/who- 
also spread globally across all continents except Antarctica.

The occurrence of the COVID-19 pandemic has certainly had a significant impact on the fabric of human life. Starting from the smallest environment, namely family, to social life. Not only that, state relations and even international relations between nations are also affected by this pandemic. But of course, vulnerable groups such as people with disabilities, the elderly, children, and women are the groups that are the hardest hit.

Apart from being affected by the disease itself, this vulnerable group is also affected by the policies taken by the government where these vulnerable groups live. For example in Indonesia. The Indonesian government, in an effort to prevent the further spread of the disease, like many other countries in the world, has chosen to implement social and physical distancing policies. The Indonesian government calls this policy the Large-Scale Social Restrictions (PSBB).

This policy turned out to have a major impact on women. Women who previously often experienced various kinds of discrimination experienced worse conditions during PSBB during this pandemic. ${ }^{2}$ This pandemic has made the injustices already felt by women and other marginalized groups such as persons with disabilities, as well as vulnerable groups who do not have the economic capacity, their condition is getting worse day by day. ${ }^{3}$

Women and these vulnerable groups must survive with all the limitations they face. Their living burden becomes heavy, especially if the area or country where they live imposes strict isolation but does not provide a guarantee of proper and equitable fulfillment of their primary needs. The lack of adequate facilities, as well as access to health services, are also a result

terhadap-perempuan-pekerja, diakses 1 Januari 2021.

3Yayasan Pulih.org. (2020). Dampak Pandemi Covid 19 Bagi Perempuan. 1 April 2020. http://yayasanpulih.org/2020/04/dampakpandemi-covid-19-bagi-perempuan/. Diakses 1 Januari 2021. 
of the economic limitations they experience. 4

Especially for women, this condition is then exacerbated by gender norms that provide boundaries for women. This gender norm makes the position of women heavier than men. As an example of patriarchal gender norms, women do not have the authority to make their own decisions, including for the needs of daily life and their reproductive needs. This decision rests with the man, be it the husband or the father. As a result, during the pandemic, most of the necessities of life are not met.

Women do not even have the autonomy to make their own reproductive-related decisions (eg to decide whether to get pregnant or not). This is further exacerbated by limited financial resources, making it difficult for women to access health services, both for themselves and for their children, especially those related to early detection of virus transmission.

On the other hand, men who have more access, tend to be reluctant to access health services for early detection

\footnotetext{
${ }^{4}$ UN Women. (2019). CEDAW \& women's human rights. $\quad 1 \quad$ Desember 2019. https://asiapacific.unwomen.org/en/focus-
}

of virus transmission because gender norms need to show that men are strong creatures. Of course, the transmission of the COVID-19 virus will not choose gender, and this behavior of wanting to appear strong can result in delays in detection, delays in treatment, and of course a higher risk of transmission. 5

The second example is related to patriarchal gender norms, men are lined up as the main breadwinners. When the government makes a quarantine policy to break the chain of transmission of the virus and make men stay at home, their gender norms as breadwinners cannot be fulfilled. This is a separate pressure, both from within him and from his family who believe that men are the main breadwinners. When household income is not fulfilled, the potential for tension and even conflict in the household becomes higher. ${ }^{6}$

The next case example related to gender norms is the unequal division of labor between men and women in the family. Gender norms instruct that men (husbands) are tasked with earning a living out of the house, while women

areas/cedaw-human-rights, diakses 31 Desember 2020.

5 Yayasan Pulih.org. Op Cit.

${ }^{6} \mathrm{Ibid}$, 
(wives) are fully responsible for household affairs such as preparing food, washing clothes, cleaning the house, and taking care of children. If the family applies discriminatory gender norms like this, the division of domestic roles is unknown.

So even though the man is staying at home, he still feels that housework is the duty of the woman (wife). This burden is even more severe if it turns out that women (wives) are workers who have to work from home too, besides having to do tasks according to their positions, women are still required to take care of their household. ${ }^{7}$ The three things above are small examples of how gender norms place women in society. Apart from the three things above, of course, there are many other injustices that women must face.

Although almost the entire population feels the impact of the COVID19 virus pandemic, of course, each person or region will experience different conditions. In the context of disaster situations and women, identified by the United Nations Population Fund (UNFPA), there are approximately 48

\footnotetext{
${ }^{7}$ Ibid,

${ }^{8}$ UN Women. Op Cit.

${ }^{9}$ Ibid,
}

million women and girls, including 4 million pregnant women, in need of humanitarian assistance and protection. The risk is greater for those who live in conflict areas, poor housing, and limited resources.

The awareness of women's rights, that women should have equal opportunities with men, became the basis for the women's rights movement in the 19th century and the feminist movement during the 20th century. ${ }^{8}$ The Convention on the Elimination of All Forms of Discrimination against Women hereinafter referred to as CEDAW, is a declaration of women's human rights internationally. ${ }^{9}$ Despite the existence of other international human rights treaties, women still do not have the same rights as men. So that additional means are needed to protect women's human rights because the fact that women are also human does not guarantee the protection of their rights. ${ }^{10}$

Indonesia has ratified CEDAW through Law Number 7 of 1984 Ratification of the United Nations Convention on the Elimination of All Forms of Discrimination against Women.

\footnotetext{
10 Savitri, Niken. (2008). HAM Perempuan, Kritik Teori Hukum Feminisme terhadap KUHP. Bandung: Refika Aditama. HIm. 1-3
} 
Even though more than three decades have passed, Indonesia still faces serious problems related to women including discriminatory policies, child marriage, and female genital circumcision. ${ }^{11}$ In addition to the three issues above, the growing problems related to discrimination and violence against women are also more complex when compared to the responsiveness and ability of the state to deal with them.

In fact, with the ratification of CEDAW, Indonesia must pay attention to the provisions stated in Article 2 of CEDAW that the participating countries condemn discrimination against women in all its forms and agree to implement by all appropriate means and without delay, the policy of eliminating discrimination against women. For this purpose, one of the participating countries must include the principle of equality between men and women in the national constitution or

\footnotetext{
11 Komnas Perempuan.go.id. (2017). Siaran Pers Komnas Perempuan: Catatan Komnas Perempuan 33 Tahun Ratifikasi Konvensi CEDAW di Indonesia. $24 \quad$ Juli 2014, https://www.komnasperempuan.go.id/readnews-siaran-pers-komnas-perempuan-catatankomnas-perempuan-33-tahun-ratifikasikonvensi-cedaw-diindonesia\#: : :text=Pers\%20Komnas\%20Peremp uan-

Catatan $\% 20$ Komnas $\% 20$ Perempuan $\% 2033 \% 20$ Tahun\%20Ratifikasi\%20Konvensi\%20CEDAW\% 20di\%20Indonesia,Pemenuhan $\% 20$ Hak\%20Pere mpuan $\% 20$ Korban $\% 20$ Kekerasan $\% \mathrm{E} 2 \% 80 \% 9 \mathrm{D}$
}

other appropriate legislation if it is not already included in it, and to ensure the practical realization of this principle, through law and by appropriate means. another proper way. ${ }^{12}$

In addition to having ratified CEDAW, Indonesia actually has several laws and regulations whose substance can be said to try to protect women's human rights. As in Law Number 39 of 1999 concerning Human Rights, through Article 46 it is emphasized that "the general election system, parties, election of members of the legislature, and the appointment system in the executive, judicial, must guarantee the representation of women according to the specified requirements. Furthermore, Article 49 paragraph 1 stipulates that women have the right to vote, to be elected, to be appointed to jobs, positions and professions in accordance with the requirements and laws and regulations.

\&text=Indonesia $\% 20$ adalah $\% 20$ salah $\% 20$ satu $\%$ 20negara,RI\%20No.\%207\%20Tahun\%201984, diakses pada 1 oktober 2020,

12 States Parties condemn discrimination against women in all its forms, agree to pursue by all appropriate means and without delay a policy of eliminating discrimination against women and, to this end, undertake: To embody the principle of the equality of men and women in their national constitutions or other appropriate legislation if not yet incorporated therein and to ensure, through law and other appropriate means, the practical realization of this principle. Article 2 point (a) CEDAW 
Even though there is more than one legislation that aims to protect women's human rights, these laws are not sufficient to protect women's human rights. This hypothesis can be drawn from the fact that cases of discrimination and violence against women are not decreasing and are increasing. ${ }^{13}$

One of the biggest challenges faced by women in Indonesia today is that apart from the ineffectiveness of these laws and regulations, there are also discriminatory policies. This discriminatory policy is in the form of legislation that is genderbiased and does not favor women, thereby perpetuating discriminatory behavior and violence against women. Under normal conditions, women often receive discriminatory treatment, and in current disaster or pandemic conditions, the potential for increased risk of genderbased violence also increases.. ${ }^{14}$

\section{B. Problem Research}

Based on the above background, the authors limit the problems that will be discussed in this study to the identification of the protection of women's human rights in Indonesia contained in the legislation. Thus, the formulation of the problems that will be discussed in this article are: (1) what are the human rights of women regulated in the existing laws and regulations in Indonesia and (2) how is the effectiveness of these regulations in protecting women, especially during this pandemic condition?

The author's purpose in researching the above problems is to identify the laws and regulations governing women's human rights and analyze them using them to determine the effectiveness of these laws and regulations in protecting women's human rights during the pandemic.

\section{Research Method}

To achieve the above objectives, this research will use a normative legal research method using a conceptual approach and a statutory approach. The collection of legal materials is carried out using a literature study and the legal materials will be analyzed using Feminist Legal Theory.

Feminist Legal Theory can be used to examine articles aimed at protecting women. Two levels are criticized by feminist legal theory, namely at the level of text and practice. Questions in feminist legal theory that can be used as

\footnotetext{
${ }^{14}$ UN Women. Op Cit.
} 
benchmarks to see how effective the law is are: (1) Does the law reflect the reality of women's experiences? Which girl? (2) What issues are covered by the law? (3) Does the law protect and benefit women? (4) Are women's aspirations and perspectives taken into account by law? The law should provide justice for women, but in some cases, legal instruments can also harm women. ${ }^{15}$

In addition to Feminist Legal Theory, this research will also use legal protection as a conceptual framework. Legal protection is protection given to human rights (HAM) that are harmed by others and this protection is given to the community so that people can enjoy all the rights granted by law. ${ }^{16}$ Law can be used to realize protection that is not only adaptive but also predictable and anticipatory. Law is needed by the weak socially, economically, and politically to realize social justice. ${ }^{17}$

The next concept that will be used in this research is the effectiveness of the

15 Irianto, Sulistyowati. (2016). Hukum Berperspektif Feminis Dibutuhkan pada Kasus Perempuan yang Terjerat Peredaran Narkotika, https://www.jurnalperempuan.org/wartafeminis/prof-sulistyowati-iriantoa-hukumberperspektif-feminis-dibutuhkan-pada-kasusperempuan-yang-terjerat-peredaran-narkotika, diakses pada 1 Oktober 2020

16 Raharjo, Satjipto. (2000). Ilmu Hukum. Bandung: PT. Citra Aditya Bakti. Hlm. 24 law. The law can be said to be effective if there is a positive legal impact, at that time the law reaches its target in guiding or changing human behavior so that it becomes legal behavior. ${ }^{18}$ Talking about the effectiveness of the law means talking about the power of the law in regulating and or forcing people to obey the law. The law can be effective if the factors that influence the law can function properly. The measure of whether or not an applicable statutory regulation is effective can be seen from the behavior of the community. A law or statutory regulation will be effective if the community members behave following what is expected or desired or the statutory regulation achieves the desired goal, then the effectiveness of the law or statutory regulation has been achieved. ${ }^{19}$

\section{ANALYSIS and DISCUSSION}

\section{A. Regulation of Women's Rights in Indonesia in the Framework of Feminist Legal Theory}

Feminist Legal Theory (FLT) being

\footnotetext{
${ }^{17}$ Arief, Barda Nawawi. (1998). Beberapa Aspek Kebijakan dan Pengembangan Hukum Pidana. Bandung: PT. Citra Aditya Bakti. HIm. 40

18 Soekanto, Soerjono. (1988). Efektivitas Hukum dan Penerapan Sanksi. Bandung: CV. Ramadja Karya. Hlm. 24-27

${ }^{19} \mathrm{Ali}$, Achmad. (1998). Menjelajahi Kajian Empiris Terhadap Hukum. Jakarta: Yarsif Watampone. Hlm: 30
} 
born is to break the legal order that is considered lame because the world is ruled by a patriarchal system. Feminists have the belief that it is the male point of view that is used to write history and, therefore, does not at all describe the role of women in the making and composing of history. The history made by men is biased so that the concepts of human existence, gender potential, and social engineering that produce language, logic, and legal structures that are created only reflect characters and values from the point of view of men only. ${ }^{20}$ To reconstruct the dominance of male thought in a patriarchal world, FLT as part of feminist studies bases its studies on women's experiences. The experience of women can be said to be a particular experience because not all women are the same, so this is subjective. ${ }^{21}$

Recognition of the principle of equality for all citizens without exception is explained in Article 27 paragraph (1) of the 1945 Constitution. This principle of equality eliminates discrimination, therefore every citizen has equal rights before the law and government

20 Asnawi, Habib Sulthon. (2011). Kritik Teori Hukum Feminis terhadap UU No. 1 Tahun 1974 tentang Perkawinan: Suatu Upaya dalam Menegakkan Keadilan HAM Kaum Perempuan. regardless of religion, ethnicity, gender. gender, position, and class. With the recognition of equal rights of citizens, it means that there is no difference between men and women. The recognition of the principle of equality before the law and government in this constitution shows that there is awareness of the importance of protecting human rights. Juridically, the laws and regulations in Indonesia have recognized the principle of equal rights between men and women. However, at the level of implementation of state administration, discrimination and injustice against women still occurs. Women are still left behind and marginalized in the fields of economy, education, health, work, as well as in politics.

One of the reasons for this backwardness of women is the patriarchal culture that develops in Indonesian indigenous peoples. The patriarchal culture in Indonesian indigenous peoples places a greater role for men than women in power. This automatically reduces the role and presence of women. Including in the

Jurnal Al-Ahwal. 4 (1). HIm. 117-130. UIN Sunan Kalijaga.

21 Lapian, L. G. (2012). Disiplin Hukum yang Mewujudkan Kesetaraan dan Keadilan Gender. Jakarta: Yayasan Obor Indonesia. Hlm. 24 
making of laws and regulations. Until now the law in Indonesia is still considered discriminatory and gender-unequal. Whereas the law should be fair to guarantee the fulfillment of human rights, including women's rights.

The principle of equal rights in all fields should be followed so that men and women have equal rights or opportunities to participate in every aspect of social and state life. So if there is discrimination against women then it can be classified as a violation of women's human rights. Violations of women's human rights occur for many reasons, including the result of a legal system that is not gender-equitable. In a legal system like this, women can become victims of the system..$^{22}$

The 1998 reformation gave birth to various laws and regulations, including laws and regulations on women's rights. This is a commendable effort by the government to eliminate discrimination based on gender as stated in the various laws and regulations. Some of the laws and regulations that were born after the Reformation period which regulates Women's Human Rights include:
1. Law Number 39 of 1999 concerning Human Rights (HAM)

In this law in Article 1 paragraph (1), human rights are defined as, "...a set of rights inherent in the nature and existence of humans as creatures of God Almighty and are His gifts that must be respected, upheld and protected by law. state, law, government, and everyone for the sake of honor and protection of human dignity". In particular, the prohibition of discrimination is regulated in Article 3 paragraph (3), which reads: "Everyone has the right to the protection of human rights and basic human freedoms, without discrimination". Meanwhile, Article 1 paragraph (3) and Article 3 paragraph (3) explain that discrimination based on sex has been prohibited by law. Based on this law, other laws must eliminate discrimination in every aspect of life, social, political, economic, cultural and legal, including discrimination against women (Kania 2015).

2. Law Number 23 of 2004 concerning the Elimination of Domestic Violence (KDRT)
22 Kania, Dede. (2015). Hak Asasi Perempuan dalam Peraturan Perundang-Undangan Di
Indonesia. Jurnal Konstitusi. 12 (4). Hlm. 716-733. Mahkamah Konstitusi Republik Indonesia. 
Prior to the issuance of this law, domestic violence was considered only as a domestic problem that did not require law enforcement, it was only enough to be resolved with kinship. Domestic violence has not been considered a violation of women's human rights, victims often do not receive adequate legal protection. This is exacerbated by the culture of Indonesian society which is dominated by patriarchal gender norms. This is very unfavorable to the position of women victims of violence because women who are victims of violence are often blamed for the violence that has befallen them. ${ }^{23}$

With the enactment of the Law on the Elimination of Domestic Violence, domestic problems that were previously considered a domestic problem have been raised to become public problems, so that the protection of victims' rights has a clear legal umbrella. Domestic violence is no longer a complaint offense, but a general offense. The scope of the household in this law is also expanded to include not only husband, wife, and children, but also people who have family relationships and live in the household as

23 Wahid, Abdul dan Irfan, Muhammad. (2011). Perlindungan Terhadap Korban Kekerasan well as people who help the household and stay in the household. ${ }^{24}$

1. Law Number 12 of 2006 concerning Citizenship

In this law, the elimination of discrimination against women contained in the previous citizenship law, namely Law Number 62 of 1958, allowed a wife, who had a mixed marriage of different nationalities, to choose her own nationality.

The provisions in Article 26 paragraphs (1) and (3) state that the wife is allowed to choose to remain in Indonesian citizenship or change citizenship according to her husband's citizenship, even though the law of her husband's country of origin requires the wife's citizenship to follow the husband's citizenship as a result of the marriage. Previously, a wife would automatically lose Indonesian citizenship if she married a male foreign national because she had to follow her husband's citizenship.

2. Law Number 21 of 2007 concerning Eradication of the Crime of Trafficking in Persons

Trafficking in persons is a form of human rights violation because it

Seksual, Advokasi atas Hak Asasi Perempuan. Bandung: Refika Aditama. Hlm. 25-30

${ }^{24}$ Kania, Dede. (2015). Op Cit. 
eliminates the basic rights of every person, namely the right to freedom. Before Law Number 21 of 2007 was born, Indonesia had provisions regarding the prohibition of trafficking in persons which were spread in several laws and regulations. Among them are Article 297 of the Criminal Code which regulates the prohibition of trafficking in women and boys who are not yet mature, as well as Law Number 23 of 2002 concerning Child Protection (UUPA) Article 83 which regulates the prohibition of trafficking, selling, or kidnapping children for themselves or sale. . However, these regulations do not clearly define the definition of trafficking in persons and only provide light and disproportionate sanctions (6 years imprisonment in Article 297 of the Criminal Code) when compared to the suffering of victims due to the crime of trafficking in persons.

This is the reason behind the promulgation of the Law on the Eradication of the Crime of Trafficking in Persons which is expected to be able to provide a formal and material legal basis at the same time. The existence of this law is proof of Indonesia's seriousness in reducing and even eliminating trafficking in persons and thus at the same time protecting the rights of human freedom, both men and especially women.

3. Law Number 2 of 2008 concerning Political Parties as amended by Law 2 of 2011 concerning Political Parties and, Law Number 8 of 2012 concerning General Elections for members of DPR, DPD, and DPRD

The two laws above formulate rules regarding a $30 \%$ quota for women at the practical level of Indonesian politics. This kind of rule can be said to be a discriminatory rule but positively (affirmative action). Affirmative action can be defined as a proactive action to eliminate discriminatory treatment against an underdeveloped social group. In this case, affirmative action is termed as women's representation which aims to open up opportunities for women so that those who have been a marginal group can be integrated into life fairly. ${ }^{25}$

All of these affirmative actions are temporary, that is until the protected groups (in this case women) have been integrated and are no longer discriminated against. This policy can be revoked if the field of competition and

25 Ibid. 
competition is fair enough for men and women to compete freely. 26

4. Presidential Instruction of the Republic of Indonesia (Inpres) Number 9 of 2000 concerning Gender Mainstreaming in National Development of the President of the Republic of Indonesia

The Presidential Instruction above was issued as an effort to improve the position, role, and quality of women, as well as efforts to realize gender equality and justice in family, community, national, and state life, it is deemed necessary to carry out a strategy of mainstreaming gender into all national development processes.

The purpose of this Presidential Instruction is to implement planning, drafting, implementing, monitoring, and evaluating national development policies and programs with a gender perspective to realize gender equality and justice in family, community, nation, and state life.

5. Presidential Regulation (Perpres) of the Republic of Indonesia Number 65 of 2005 concerning the National Commission on Violence Against

\footnotetext{
${ }^{26}$ Ibid.

27 To establish legal protection of the rights of women on an equal basis with men and to ensure through competent national tribunals and other
}

Women with the Grace of God Almighty President of the Republic of Indonesia

The Presidential Decree above is a substitute for Presidential Decree (KEPPRES) No. 181 of 1998 concerning the National Commission on Violence Against Women.

This Presidential Regulation is a form of government effort as a follow-up step to the ratification of CEDAW and the Convention Against Torture and Other Cruel, Inhuman or Degrading Treatment or Punishment by Indonesia.

Article 2 point (c) states that States parties must uphold the legal protection of women's rights on an equal basis with men and to ensure through competent national courts and other government bodies, the effective protection of women against any act of discrimination. ${ }^{27}$

The explanation above has identified laws and regulations that have given special treatment to women, or at least have been prepared with a gender equality perspective, apart from what has been mentioned above, of course, there are still laws and regulations that are felt

\footnotetext{
public institutions the effective protection of women against any act of discrimination. Article 2 poin (c) CEDAW
} 
to be discriminatory against women, or not yet gender-sensitive

Until now, the provisions of the laws and regulations that were made during the Dutch colonial administration such as the Criminal Code (KUHP) can still be found. This KUHP has the original name Wetboek van Strafrecht voor Nederlandsch Indie (WvSNI) which was enforced in Indonesia for the first time with Koninklijk Besluit (King's Decree) Number 33, 15 October 1915 and came into force on 1 January 1918 . WvSNI is a derivative of state WvS Netherlands created in 1881 and enforced in the Netherlands in 1886.28 Although this WvSNI is a derivative of the Dutch WvS, the colonial government at that time applied the principle of concordance (adjustments) for the implementation of WvS in its colonies (Indonesia or the Dutch East Indies at that time) by abolishing several articles and adjustments to the conditions and mission of Dutch colonialism over the territory. Indonesia. ${ }^{29}$

Of course, the 102-year-old Criminal Code does not recognize gender-

\footnotetext{
${ }^{28}$ Savitri, Niken. Op Cit. Hlm. 5-6

${ }^{29}$ Ibid.

${ }^{30}$ Kania, Dede. Op Cit.

31 Savitri, Niken. Op Cit. HIm. 43-50
}

based violence. This can be seen from the formulation of articles that define violence against women and articles related to sexual crimes categorized as crimes of decency and not crimes against the integrity of women's bodies. ${ }^{30}$. Another example of a gender-biased article in the Criminal Code is Article 346 of the Criminal Code which threatens punishment for women who have abortions. Although the purpose of this article is to protect human life from the time they are in the womb, on the other hand, this article also makes women have no rights over their bodies and have no autonomy over themselves. ${ }^{31}$

In addition to the Criminal Code, other laws and regulations that do not pay attention to aspects of gender justice even though they are related to women are Law Number 1 of 1974 concerning Marriage. The marriage law stipulates the age limit for women to be allowed to marry is 16 years. This makes the gap between boys and girls even bigger. With an early age limit for marriage, girls will lose the opportunity to get higher education. ${ }^{32}$ In addition to the age limit,

\footnotetext{
32 Kompas.com. (2016). Diskriminasi Gender, Tujuh UU Terkait Perempuan Ini Perlu Diubah. 6 Maret 2016. https://nasional.kompas.com/read/2016/03/06 /17335421/Diskriminasi.Gender.Tujuh.UU.Terka
} 
another gender inequality identification is the domestication of women, namely the placement of the wife as a housewife in Article 31 paragraph (1), and that the husband's obligation to provide for it thus minimizes the role of women/wives because they are considered not to have the ability to earn a living and to meet the needs of family life, including children. ${ }^{33}$

There are many other examples of laws and regulations that do not reflect gender justice. One way to achieve gender justice for women in-laws and regulations is to increase the number of women who become members of parliament, until now the number of women DPR members has never reached $30 \%$.

Indonesia already has laws and regulations which at the formal legal level (normally) can almost be said to have fulfilled a sense of justice and thus reduced gender bias. However, norms that fulfill a sense of gender justice alone will not be sufficient if they are not followed by gender-sensitive law enforcement. And what is no less important is the change in society's culture from one that tends to

it.Perempuan.Ini.Perlu.Diubah. Diakses pada 31 Desember 2020 discriminate against women to a culture that reflects the recognition of women's rights. It should be remembered that the struggle of women in ending an unfair system (gender injustice) is not a struggle of women against men, but a struggle against the system and structure of society's injustice, in the form of gender injustice.

\section{B. Measuring the Effectiveness of Protecting Women's Human Rights during a Pandemic}

In the previous section, the laws and regulations governing the protection of women's rights in Indonesia have been identified. It must also be remembered that Indonesia has ratified CEDAW through Law Number 7 of 1984 Ratification of the United Nations Convention on the Elimination of All Forms of Discrimination against Women. This ratification indicates that Indonesia also recognizes the forms of women's human rights regulated in CEDAW. ${ }^{34}$

Women's human rights in Indonesia have been stated in the legislation. However, the practice of enforcing these regulations is not as easy as turning the palm of the hand. Legal protection cannot

\footnotetext{
${ }^{33}$ Ibid

${ }^{34}$ Komnas Perempuan.go.id. Op Cit.
} 
be separated from the context of law enforcement. Law enforcement is an attempt to bring the ideas of justice, legal certainty, and social benefits into reality. Law enforcement is essentially a process of realizing ideas, processes carried out, efforts to enforce or actually function legal norms as guidelines in social and state life. Law enforcement is an effort to realize the ideas and legal concepts that are expected by the people to become a reality.

When the law is upheld, then effectiveness can be measured. The effectiveness of the law can be measured by the extent to which the rule of law is obeyed or not. More generally, the factors that greatly affect the effectiveness of law are professionalism and optimization of the implementation of the roles, authorities, and functions of law enforcers, both in explaining the tasks assigned to them and in enforcing the legislation. Law can be said to be effective if there is a positive legal impact, at that time the law reaches its target in guiding or changing human behavior so that it becomes legal behavior.
The Covid-19 pandemic was initially detected in December 2019 and in mid-January 2020, this virus quickly spread throughout the world so that in no time millions of people were infected and hundreds of thousands of people died. In every affected country, almost all local governments apply lockdown and social distancing rules to reduce the spread of this virus. The Covid-19 pandemic has not only resulted in a health crisis but also an economic and social crisis arising from the situation of these restrictions. It can be said that the Covid-19 pandemic has created a crisis, and in a crisis situation the most vulnerable groups are marginal groups such as women and girls. In a state of crisis, inequality, inequality, exploitation, discrimination, and violence are always present and increasing. 35 Protection of women's human rights should be carried out at all times, not only during a pandemic but also under normal conditions. However, the patriarchal structure of society that holds tightly to gender norms that discriminate against women makes this effort to protect women's human rights not optimal.
35 Arivia, Gadis (2020), Feminisme dan Covid-19, https://www.jurnalperempuan.org/wacana-

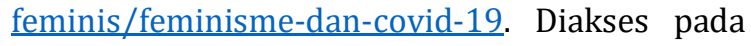
31 Desember 2020 
The analysis of the effectiveness of legal protection for women's human rights in this section will focus on the form of violation of women's human rights that increased sharply during the pandemic, namely violence against women. Until May 2020, violence against women reached 892 cases (based on complaints), of which the highest number of violence, especially domestic violence (KDRT), was $69 \%$ of the total number of recorded cases. ${ }^{36}$ Normatively, Indonesia already has Law No. 23 of 2004 on the Elimination of Domestic Violence (UU PKDRT). If it is concluded based on cases of domestic violence that still occur frequently, it can be said that this law has not been effective in protecting women from domestic violence.

The PKDRT Law in Article 1 paragraph (2) states that the elimination of domestic violence is a guarantee given by the state to prevent domestic violence, take action against perpetrators of domestic violence, and protect victims of domestic violence. Based on this formulation, it can be concluded that the PKDRT Law contains three dimensions,

\footnotetext{
${ }^{36}$ Katadata.co.id. Op Cit.

37 Pratama, Dika. (2019), Efektivitas Penegakan Undang-Undang Penghapusan Kekerasan dalam Rumah Tangga Nomor 23 Tahun 2004 di
}

namely prevention, prosecution, and protection. ${ }^{37}$

If based on the data on the number of reports on cases of domestic violence that occurred, it can be concluded that the trend in the number of domestic violence has increased. This quantitative data does not always mean that the number of domestic violence is increasing, because it could be because victims of domestic violence are now starting to dare to report to the authorities. The number of reports of domestic violence that continues to increase can also be interpreted that the law enforcement dimension of the PKDRT Law can be said to be quite effective (measured by the number of incoming reports). Incoming reports indicate that law enforcement officers are trusted by the community (reporters) to take action against domestic violence cases. However, if the increasing number of reports is interpreted in the context of prevention, it can be concluded that the PKDRT Law is not effective in preventing the occurrence of domestic violence. The higher the number of domestic violence

Yogyakarta, Jurnal Lex Renaissance, 2 (4). Hlm. 367-385. Universitas Islam Indonesia, Yogyakarta. 
reports that come in indicates that the aspects of preventing and protecting domestic violence against women by the PKDRT Law can be said to be ineffective.

Another form of violence against women that has increased during the pandemic is sexual violence. Sexual violence that occurs against women can be classified based on their relationship, namely sexual violence that occurs in the household or in personal relationships, and sexual violence that occurs in the Community Realm. For sexual violence that occurs in households or personal relationships, the PKDRT Law can be used as a legal umbrella. However, for sexual violence that occurs in the community, the available legal umbrella is still lacking, the articles that regulate sexual violence in the Criminal Code have a criminal threat that is not maximal (too light when compared to the suffering of the victim), this is coupled with the process in procedural law. criminal proceedings ranging from reporting processes to examinations in courts that are not victim-friendly ${ }^{38}$. These reasons make victims of sexual violence in the

38 Wahid, Abdul dan Irfan, Muhammad. Op Cit. HIm. $81-83$

39 Ridhoi, Muhammad Ahsan, "Kekerasan terhadap Perempuan di Masa Covid-19 - Analisis community even more reluctant to report.

For online sexual violence, Komnas Perempuan recorded a total of 354 cases of online gender-based violence (KBGO) during January-May 2020 in all domains. This number is more than the total report in 2019 which was 281 cases. ${ }^{39}$ Cases of online sexual violence are a new form of sexual violence cases that also increased sharply during the pandemic and this form of sexual violence does not have a legal umbrella. For example, in the case of revenge porn, if using Law Number 44 of 2008 concerning Pornography (Pornography Law), victims of online sexual violence can also be ensnared. Victims may be considered as "content creators who violate decency" and may be subject to criminal penalties for this. This of course fulfills a sense of justice because the victim can be a victim twice. Law Number 11 of 2008 concerning Information and Electronic Transactions as amended by Law Number 19 of 2016 concerning Amendments to Law Number 11 of 2008 concerning Electronic Information and Transactions (UU ITE)

\footnotetext{
Data Katadata", Katadata.co.id, https://katadata.co.id/0/analisisdata/5f696191 21b54/kekerasan-terhadap-perempuan-dimasa-covid-19, diakses 1 Januari 2021
} 
has regulated the punishment for perpetrators of spreading content that violates decency, but the dimension of victim protection in this law is also weak.

Based on the identification of the cases above, it can be concluded that the protection of women's human rights that have been regulated in the legislation is still not effective in protecting women from violations of their human rights, namely to be free from all kinds of violence. Especially in cases of sexual violence that increased during the pandemic, the lack of a legal umbrella meant that the Draft Law on the Elimination of Sexual Violence (RUU PKS) should be returned to the national legislation program. It is hoped that this law will ensure that women are free from threats of sexual violence.

Whether or not a law is effective or not is influenced by at least 5 (five) factors, namely: (a) the legal factor itself (legal substance), (b) law enforcement factors (the party who makes and applies the law), (c) the target factor or facilities provided support law enforcement, (d) community factors, namely the environment in which the law applies or is applied and (e) cultural factors as a result of creative works and feelings based on a human initiative in association ${ }^{40}$. Although the substance of the rule of law is classified as good, if other factors do not support it, the effectiveness of the law will also not be achieved.

In the context of handling cases of violence against women, the challenges faced are from the structure of law enforcement and legal culture. In law enforcement, women as witnesses and victims need certain conditions to be able to give information freely without pressure. So that in the process of handling cases, starting from investigation, investigation, prosecution, to trial, special conditions are needed to accommodate women. For example, when an investigation is conducted, women victims of sexual violence certainly need their own space because not all women can openly convey what they have experienced. Likewise, if it is related to the trial, women need security guarantees both physically and psychologically to be able to feel safe and calm. This condition is often not presented by law enforcement officers who handle the case. This shows that law

${ }^{40}$ Kania, Dede. Op Cit. 
enforcement officials have not prioritized the interests of victims so that access to justice for victims is not fulfilled and victims lose their rights to protection.

Legal culture is the public's perspective on legal issues that occur. In the context of violence against women, which is currently being built to care for women, most of the community still considers violence against women to exist, let alone domestic violence as a domestic sphere. This causes the interests of women victims of violence to sink into larger interests, such as the good name of their families and communities. An example is a case of violence in the form of abuse by a husband against his wife, people tend to regard the problem as a personal problem that cannot be interfered with by other people, especially law enforcement officers. This causes the rights of victims to be neglected and thus the community also participates in perpetuating the occurrence of the crime itself.

The identification of the problems above shows that the existence of laws and regulations alone cannot guarantee the implementation of women's human rights. Legislation must be followed by gender-sensitive law enforcement and no less important is a cultural change in society. To change certain cultural values is not an easy thing, it cannot even be done by legal coercion. A more appropriate way is to reconstruct local cultural values that reflect the recognition of women's rights so that they can be easily accepted by the community. This is because public knowledge is very important in the context of providing input in the process of enforcing justice against victims.

\section{CONCLUSION}

Indonesia already has laws and regulations which at the formal legal level (normally) can be said to have fulfilled a sense of justice and thus reduced gender bias. As for some women's human rights that have been regulated in the laws and regulations in Indonesia, among others: (1) The right to be free from gender discrimination (UU HAM); (2) The right to justice and gender equality (Human Rights Law, PKDRT Law); (3) The right to get protection as a victim (UU PKDRT); (4) The right to recognition and respect for human rights in all matters relating to citizens (Citizenship Law); (5) The right to be free from racial discrimination (UU PTPPO); (6) Political Rights (Law on Political Parties, Law on Elections); and 
(7) The right to be free from discriminatory treatment against a social group that is still backward (Law on Political Parties, Law on Elections)

Based on the analysis of the effectiveness of these laws and regulations, by focusing on the legal protection aspect only, namely the protection against violence (both physical and sexual) against women, it shows that the existing legal umbrella has not been effective enough to protect women. This is because the existence of laws and regulations alone cannot guarantee the implementation of women's human rights. Legislation must be followed by gender-sensitive law enforcement and no less important is a cultural change in society.

In addition to ensuring the availability of a legal umbrella, the enforcement of women's human rights laws that guarantee the protection of women must also be carried out with the following things:

Reconstructing the paradigm of society on the role of women. The struggle of women in ending an unjust system is a struggle against the system and structure of society's injustice in the form of gender injustice. Women often become double victimization, because apart from being victims of the crime itself, they are also victims of stigma by society. The paradigm of society that discriminates against women must be reconstructed. Introducing gender equality from an early age should be done to both boys and girls. This is important to do so that there is an understanding that men and women are human beings who have equal rights in every aspect of their lives.

\section{REFERENCE}

\section{Books}

Arief, Barda Nawawi. (1998). Beberapa Aspek Kebijakan dan Pengembangan Hukum Pidana. Bandung: PT. Citra Aditya Bakti.

Ali, Achmad. (1998). Menjelajahi Kajian Empiris Terhadap Hukum. Jakarta: Yarsif Watampone.

Lapian, L. G. (2012). Disiplin Hukum yang Mewujudkan Kesetaraan dan Keadilan Gender. Jakarta: Yayasan Obor Indonesia.

Raharjo, Satjipto. (2000). Ilmu Hukum. Bandung: PT. Citra Aditya Bakti.

Savitri, Niken. (2008). HAM Perempuan, Kritik Teori Hukum Feminisme terhadap KUHP. Bandung: Refika Aditama.

Soekanto, Soerjono. (1988). Efektivitas Hukum dan Penerapan Sanksi. Bandung: CV. Ramadja Karya.

Soetjipto, Ani Widyani. (2005) Politik Perempuan Bukan Gerhana. Jakarta: Penerbit Buku Kompas. 
Wahid, Abdul dan Irfan, Muhammad. (2011). Perlindungan Terhadap Korban Kekerasan Seksual, Advokasi atas Hak Asasi Perempuan. Bandung: Refika Aditama.

\section{Journal}

Asnawi, Habib Sulthon. (2011). Kritik Teori Hukum Feminis terhadap UU No. 1 Tahun 1974 tentang Perkawinan: Suatu Upaya dalam Menegakkan Keadilan HAM Kaum Perempuan. Jurnal Al-Ahwal. 4 (1): 117-130. UIN Sunan Kalijaga.

Kania, Dede. (2015). Hak Asasi Perempuan dalam Peraturan Perundang-Undangan Di Indonesia. Jurnal Konstitusi. 12 (4): 716-733. Mahkamah Konstitusi Republik Indonesia.

Pratama, Dika. (2019), Efektifitas Penegakan Undang-Undang Penghapusan Kekarasan dalam Rumah Tangga Nomor 23 Tahun 2004 di Yogyakarta, Jurnal Lex Renaissance, 2 (4): 367-385. Universitas Islam Indonesia.

Artikel dari Internet

Arivia, Gadis (2020), Feminisme dan Covid-19, https://www.jurnalperempuan.org /wacana-feminis/feminisme-dancovid-19. Diakses pada 31 Desember 2020

Ridhoi, Muhammad Ahsan, "Kekerasan terhadap Perempuan di Masa Covid-19 - Analisis Data Katadata", Katadata.co.id, https://katadata.co.id/0/analisisda ta/5f69619121b54/kekerasan- terhadap-perempuan-di-masacovid-19, diakses 1 Januari 2021

Irianto, Sulistyowati. (2016). Hukum Berperspektif Feminis Dibutuhkan pada Kasus Perempuan yang Terjerat Peredaran Narkotika, https://www.jurnalperempuan.org /warta-feminis/prof-sulistyowatiiriantoa-hukum-berperspektiffeminis-dibutuhkan-pada-kasusperempuan-yang-terjeratperedaran-narkotika, diakses pada 1 Oktober 2020

\section{Website}

Katadata.co.id. (2020). Pandemi COVID19 Berdampak Ganda terhadap Perempuan Pekerja. 29 Agustus 2020,

https://katadata.co.id/ekarina/ber ita/5f49434c76849/pandemicovid-19-berdampak-gandaterhadap-perempuan-pekerja, diakses 1 Januari 2021.

Komnas Perempuan.go.id. (2017). Siaran Pers Komnas Perempuan: Catatan Komnas Perempuan 33 Tahun Ratifikasi Konvensi CEDAW di Indonesia. 24 Juli 2014, https://www.komnasperempuan.g o.id/read-news-siaran-perskomnas-perempuan-catatankomnas-perempuan-33-tahunratifikasi-konvensi-cedaw-diindonesia\#: : text=Pers\%20Komna s\%20Perempuan,Catatan\%20Komnas\%20Perempu an\%2033\%20Tahun\%20Ratifikasi $\% 20$ Konvensi\%20CEDAW\%20di\% 20Indonesia,Pemenuhan\%20Hak\% 20Perempuan\%20Korban\%20Kek erasan\%E2\%80\%9D\&text=Indone sia\%20adalah\%20salah\%20satu\% 20negara,RI\%20No.\%207\%20Tah 
un\%201984, diakses pada 1

oktober 2020,

Kompas.com. (2016). Diskriminasi Gender, Tujuh UU Terkait Perempuan Ini Perlu Diubah. 6 Maret 2016. https://nasional.kompas.com/read /2016/03/06/17335421/Diskrimi nasi.Gender.Tujuh.UU.Terkait.Pere mpuan.Ini.Perlu.Diubah. Diakses pada 31 Desember 2020

Tempo.co. (2020). WHO Tetapkan COVID 19 sebagai Pandemi, Apa Maksudnya?. 12 Maret 2020. https://dunia.tempo.co/read/1318 511/who-tetapkan-covid-19sebagai-pandemi-apamaksudnya/full\&view=ok, diakses 1 Januari 2021,

UN Women. (2019). CEDAW \& women's human rights. 1 Desember 2019. https://asiapacific.unwomen.org/e n/focus-areas/cedaw-humanrights, diakses 31 Desember 2020.

Yayasan Pulih.org. (2020). Dampak Pandemi Covid 19 Bagi Perempuan. 12020. http://yayasanpulih.org/2020/04/ dampak-pandemi-covid-19-bagiperempuan/. Diakses 1 Januari 2021. 